\title{
Cultural Preservation Through ICT amongst Ethnic Minorities in Malaysia
}

Choo Yeong Khong, Sarjit S. Gill, Asnarulkhadi Abu Samah, A. T. Talib

To Link this Article: http://dx.doi.org/10.6007/IJARBSS/v11-i11/11665 DOI:10.6007/IJARBSS/v11-i11/11665

Received: 27 September 2021, Revised: 30 October 2021, Accepted: 07 November 2021

Published Online: 26 November 2021

In-Text Citation: (Khong et al., 2021)

To Cite this Article: Khong, C. Y., Gill, S. S., Samah, A. A., \& Talib, A. T. (2021). Cultural Preservation Through ICT amongst Ethnic Minorities in Malaysia. International Journal of Academic Research in Business and Social Sciences, 11(11), 1848-1861.

\section{Copyright: @ 2021 The Author(s)}

Published by Human Resource Management Academic Research Society (www.hrmars.com)

This article is published under the Creative Commons Attribution (CC BY 4.0) license. Anyone may reproduce, distribute, translate and create derivative works of this article (for both commercial and non0-commercial purposes), subject to full attribution to the original publication and authors. The full terms of this license may be seen at: http://creativecommons.org/licences/by/4.0/legalcode

Vol. 11, No. 11, 2021, Pg. $1848-1861$

Full Terms \& Conditions of access and use can be found at http://hrmars.com/index.php/pages/detail/publication-ethics 


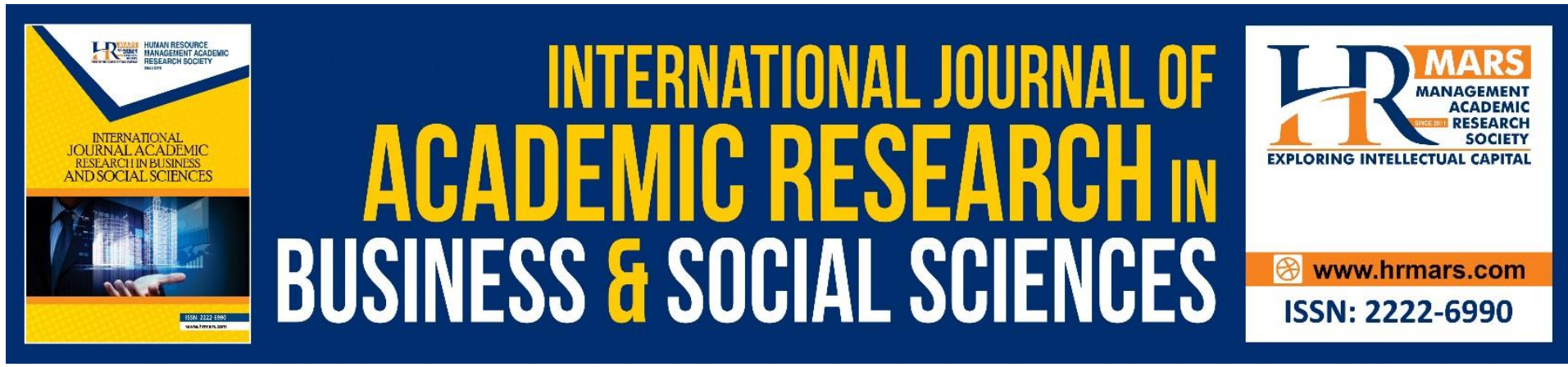

\title{
Cultural Preservation Through ICT amongst Ethnic Minorities in Malaysia
}

\author{
Choo Yeong Khong, Sarjit S. Gill, Asnarulkhadi Abu Samah
} Department of Social and Development Science, Faculty of Human Ecology, Universiti Putra Malaysia, 43400 Serdang, Selangor.

Email: sarjit@upm.edu.my

\author{
A. T. Talib \\ Department of Government and Civilizational Studies, Faculty of Human Ecology, Universiti \\ Putra Malaysia, 43400 Serdang, Selangor.
}

\begin{abstract}
Information and Communication Technology (ICT) has gradually evolved into a necessity for all members of society, whether in urban or rural areas. As ICT has penetrated almost every aspect of human daily lives, its impact on the culture and identity of ethnic minorities has been widely debated in recent years. On the one hand, ICT has been labelled as the catalyst that eroded the culture of the ethnic minorities; on the other hand, it has the potential to play a critical role in preserving the ethnic minorities' endangered culture. This is worth pondering as many ethnic minorities in Malaysia are facing the threat of losing their cultural identity through various means such as being assimilated into mainstream society, can ICT be a beneficial instrument for cultural preservation to enhance the ethnic minorities' cultural survival, or is it simply a rhetorical thought? Therefore, this article is significant as it endeavours to discuss the factors for the decline of the ethnic minorities' cultural identity and aims to broaden perspectives on ICT and ethnic minorities' cultural research in Malaysia.
\end{abstract}

Keywords: ICT, Ethnic Minorities, Assimilation, Cultural Identity, Preservation

\section{Introduction}

Information and Communication Technology (ICT) is deemed to be a necessity in daily human lives in this information era (Menon \& Fink, 2019). The penetration of ICT in almost every aspect of human life has significantly altered the style of communication with one another (Acilar, 2011; Roztocki et al., 2019). The prevalence of ICT promotes interconnectedness and intercultural adaptation among the multiracial and multicultural society (Sawyer et al., 2012). This has raised numerous debates that viewed ICT as a double-edged sword in terms of cultural preservation. Some scholars have expressed concerns that ICT, which is embedded with alien values, is gradually eroding local cultural values, while others insist that ICT has great potential in enriching local cultural values through positive foreign influences (Ekeanyanwu, 2010). 
All segments of Malaysian society must benefit from the country's economic prosperity in order to create an advanced economy and inclusive nation by 2020. A nation-wide survey, namely the Internet Users Survey 2014, stated that the Malay users made up $67.0 \%$ of the total, while Chinese users made up 17.8\%. Bumiputra Sabah/Sarawak accounted for $8.2 \%$, Indian (6.2\%), while Orang Asli and others made up 0.7\% (Malaysian Communications and Multimedia Commission, 2014). In comparison to other mainstream societies, it has been observed that the Orang Asli are digitally underprivileged. A study carried out by Hashim et al (2012) indicated that there was only 5.2\% of the Semai tribe resided in a rural area of Perak were computer literate. Generally, there is a lack of opportunities for the ethnic minority communities, especially the digital divide faced by the youth, who will be future leaders of the country. Are their problems not important and critical to be brought to the attention of the respective authorities? These digital divide problems should be addressed carefully as these people are also part of the community that would determine the future of Malaysia. Therefore, this article is crucial since it attempts to discuss the status of ICT adoption in cultural preservation among the ethnic minorities in Malaysia. The article is divided into three main sections. The first part traces, describes, and analyses ICT and its development and participation among Malaysia's ethnic minorities. The second part focuses on the factors that contribute to the decline of ethnic minorities' cultural identities. The final part focuses on ethnic minorities' cultural preservation through ICT.

\section{Methodology}

This paper reviews previous studies to provide a comprehensive description of ICT development and participation among Malaysia's ethnic minorities, as well as the role of ICT in cultural preservation. Peer-reviewed scholarly literature and administrative data generated by local governments or international agencies were included in the review. Snyder (2019) suggested that literature reviews are more important than ever as a research method since it is a good mean of integrating interdisciplinary research findings to demonstrate evidence on a meta-level and to identify areas where additional study is needed.

\section{Information and Communication Technology (ICT) and Its Development in Malaysia}

Humans are greatly relying on ICT in managing and accomplishing tasks in their daily lives. Various definitions of ICT have emerged in this digital era. ICT is defined as technologies comprising hardware, software, internet, media and telecommunications, all of which are used to gather and transmit information electronically (Apulu \& Latham, 2011; Zuppo, 2012). These technologies include radio, televisions, computers, projectors, and the internet (Bhawna, 2019). Kaware and Sain (2015) described ICT as electronic tools and resources for manipulation and communication of information which is vital in facilitating learning in daily life.

ICT can be viewed as the technological devices and infrastructures used to generate, gather, process, store, distribute information and bring value-addition which is crucial in sustaining socioeconomic development (Arrawatia \& Meel, 2012; Borgmann, 2006). This is in line with Yamamichi (2011) who suggested that ICT is a general description for various types of digital devices, software, applications and telecommunications tools that could be used to generate, analyze, process, and disseminate information. There is no universal definition of ICT, but various definitions of ICT are similar as described by United Nations (2003) which stated that "ICTs are information-handling tools - a varied set of goods, applications and services that are 
used to produce, store, process, distribute and exchange information. They include the "old" ICTs of radio, television and telephone, and the "new" ICTs of computers, satellite and wireless technology and the Internet". Therefore, ICT can be concluded as a wide range of digital technologies that facilitate information transmission and human communication.

Malaysia's government is aware of the benefits gained from the ICT development thus putting great commitment to facilitate extensive adoption of ICT among the citizens in the urban and rural area (Osman, 2007). To achieve Vision 2020 and to become a developed country with the establishment of K-community (knowledge community), Malaysia has invested substantially in ICT development in terms of money, time and human resources. Although Vision 2020 has not been fully realised, however it saws some success for the past decades and set up a crucial foundation especially in enhancing ICT competency among the citizens through various agencies and policies such as the establishment of the National Information Technology Council (NITC), Malaysian Communications and Multimedia Commission (MCMC), Multimedia Super Corridor (MSC), E-Bario project, Wi-Fi Community, Smart Community and the establishment of Malaysian Administration, Modernisation and Management Planning Unit (MAMPU) as the lead agency in the public sector for ICT development.

The investments for ICT development expanded at a rate of 9.2 per cent per annum from RM3.8 billion in 1995 to RM5.9 billion in 2000 in Seventh Malaysia Plan (Economic Planning Unit Malaysia, 2001). During the Eighth Malaysia Plan, a total of RM5.2 billion was allocated for ICT-related programmes and projects (Economic Planning Unit Malaysia, 2006). The success of both plans in increasing the ICT penetration among the citizens then motivated the Malaysian government to continue paying greater attention during the Ninth Malaysian Plan (2006-2010) and Tenth Malaysian Plan (2011-2015) to improve the infrastructure and accessibility to ICT among its citizens. For instance, the government has undertaken tremendous efforts in providing more affordable ICT products and services to bridge the digital divide, and it is reported that $90.1 \%$ of households have internet connections in 2019 (Department of Statistics Malaysia, 2019).

ICT development in Malaysia is more significantly observed after the launching of another national vision, National Transformation 2050 (TN50) and Shared Prosperity Vision 2030, which aims to transform Malaysia to be a united, dignified and developed nation in terms of economic, citizen well-being and innovation in technology and science. The increasing global ICT advancement and competition have encouraged the Malaysian government to put greater concerns on the development of its ICT sector. As a result, the Eleventh Malaysian Plan (2016-2020) emphasizes on ICT development as a crucial enabler for a knowledge economy, in order to boost national productivity and competitiveness through innovation. This can be seen through the determination of the government to embrace the digital economy. The digital economy is expected to contribute about RM 267.7 billion or $18.5 \%$ to the national economy by 2018 (Department of Statistics Malaysia, 2018). ICT is seen as an imperative enabler of economic growth and as key to improve the quality of life of the citizens (Ishak \& Hassan, 2007). It is hoped that the advanced technologies adoption can transform Malaysia into a highly competent nation, promoting a digital-cultured and knowledge-based society. 


\section{Participation of Ethnic Minorities in ICT Development}

While various ICT development policies and projects have been implemented, the extent to which ethnic minorities can get involved and benefit from the ICT development remains questionable. In Malaysia's context, one of the strategies adopted to include ethnic minorities in the national ICT development is through their participation in the national education system. The Malaysian government has recognized the great potential of ICT in transforming education and thus introduced the Malaysia Education Blueprint 2013-2025, which aims to enhance the learning process and introduce proven ICT solutions in the education system. The UNESCO review indicated that Malaysia was among the first few countries in the world to have pioneered a strategic ICT plan for its education. For instance, the government has invested about RM6 billion in ICT in education initiatives from 1999 to 2010 (Ministry of Education Malaysia, 2013). The blueprint emphasizes reducing the education gap that exists in the country in terms of physical and non-physical facilities, performance and achievements of students and school dropouts. Concurrently, it also aims to reduce the digital gap in rural and remote areas.

Nonetheless, this ideal strategy remains as a rhetoric if the dropout rate is still high because the education gap that exists will be further widening the digital divide among citizens. For instance, despite the positive decline of the school dropout rate among the Orang Asli students in recent years, the dropout rate is still relatively high especially from the transition phase from primary school to secondary school and, poor academic performance remains a great concern (Rosnon \& Talib, 2019). Ethnic minorities, with their small population, are undeniably disadvantaged in terms of being equally participating and benefiting from Malaysia's national development as other dominant communities. Indeed, they have always been the groups being marginalized from mainstream socio-political development and struggling for equal treatment in terms of land rights, political participation and education participation (Ashraf et al., 2015; Edo et al., 2013). Gill et al (2009) indicated that ethnic minorities especially Orang Asli communities are experiencing a digital divide, not because of their values and beliefs, but rather due to insufficient knowledge, skills and infrastructure to facilitate their access to ICT.

\section{Factors Contributing to the Decline of Ethnic Minority Cultural Identity}

Many ethnic minorities in Malaysia are facing the threat of losing their cultural identity through various means of assimilation into the mainstream society (Fernandis, 2003; Gill et al., 2015; Lee, 2008; Masron et al., 2013). This has further pressured the ethnic minorities in preserving their cultural identity. Some factors that lead to the decline of the ethnic minorities culture were modernization and socialization with other groups (Lee, 2008; Moorthy, 2009). Modernization comes along with various development programmes has led to ceaseless land development in Malaysia. This has placed the Orang Asli communities in a dilemma because rejecting such development will cause them to be labelled pejoratively as "anti-development" or "backward", while accepting the development means they will be dispossessed from their native customary land for the sake of "development", which might not considerably benefit them. The land is not just an important main source of livelihood for the Orang Asli, but it also embodies their cultural identity as they believe that the land has spiritual and cultural values attached to it (Masron et al., 2013). Therefore, dispossession of it means it negatively affects their culture and identity. 
Furthermore, some ethnic minorities are more likely to integrate their cultures with other mainstream society as a result of globalisation, altering or replacing their traditional customs, rituals and practices in favor of simpler, less time-consuming and less expensive celebrations (Oh et al., 2019). The practices of some festivals of the ethnic minorities in Malaysia are diminishing in this modern era. For instance, Lee (2008) indicated that the Wangkang festival which involves days of prayers and fasting is barely seen nowadays among the Baba Nyonya community. Other festivals such as the Winter Solstice Festival, Chinese New Year, and weddings are still practised in certain households, but regrettably many of the traditional customs and rituals involved have been abandoned and disappearing due to the heavy demands of modern lifestyle (Lee, 2008).

Language is the key ingredient of ethnic identity (Reid, 1997). Pinto (2019) stated that the introduction of colonizer's formal education has led to the emergence of a new lifestyle, language and culture to the local society. They are now adopted and adapted a new system with its different set of values and patterns of behaviour to fit into a new economic system that is different from their traditional system. The concept of nation-state seeks to redefine identities by ensuring every citizen speaks one standard national language through a compulsory education system, which might endanger many ethnic minorities' languages. It is a crucial endeavor with a noble goal of fostering national unity and creating a shared national identity. However, it eventually leads to a decline in the usage of the mother tongue among ethnic minorities, as the domain of Bahasa Malaysia has increasingly widened.

The ethnic minorities are facing a dilemma that they are being torn between preserving their mother tongue and use the dominant Bahasa Malaysia which allows them to fully function socially and economically (Kijai, 2012). The languages of the ethnic minorities always struggle to survive due to the dominant use of Bahasa Malaysia (Malay language) as the national language and English as the language widely used in business and education (Pillai et al., 2015). Lee (2008) indicated that many customs, rituals and language of the Baba Nyonya communities were less practised from one generation to the other. She pointed out that the unique Peranakan language is currently under pressure from the Malay language, English and Mandarin. There is a resemblance to a research by Gill et al (2015) who highlighted that the Sikh community's language in Malaysia is under threat due to the dominance of other main languages. Masron et al (2013) asserted that the erosion of minorities' cultural identity is being exacerbated by an inappropriate education system that fails to accommodate their beliefs and practices. This is in line with the argument of Nicholas (1996) who stated that the policy of integration has started in the 1960s to integrate Orang Asli into the mainstream society.

Religion is another aspect of the ethnic minorities' cultural identity which is under threat. For instance, indigenous religious beliefs or animism revolve around the existence of spirits in objects. Proselytization has been actively carried out in recent years (Carey, 1970; Liu, 2021; Masron et al., 2013; Nicholas, 1996). The state-led Islamization policy and nongovernmental Christian missions toward the Orang Asli have had significant impacts on their cultural identity (Arabestani \& Edo, 2011; Nobuta, 2007). Inter-ethnic marriage or interfaith marriage is one of the most significant factors that contribute to the conversion to other religious beliefs among the ethnic minorities which substantially changes their cultural identity (Gill et al., 2015; Sintang et al., 2014). 


\section{Cultural Preservation through ICT among the Ethnic Minorities}

Globalization and the advent of the Fourth Industrial Revolution characterized by the rapid innovation of technologies have tremendously changed the ways society interact and communicate with one another, including among Malaysia's ethnic minorities. Our cultures, traditions, collective memories, and values are transmitted via our languages. They are an integral part of our identities, as well as a foundation of diversity and living heritage. Nonetheless, approximately half of the world's 6,000 languages are in risk of extinction (UNESCO, 2011). The death of the language speakers, intermarriage, cultural contact and clash, lack of economic opportunities, repression and official language policy are among the main factors that contributed to the language death (Wurm, 1991). Indeed, English has become the worldwide primary language used for international commerce, science and technology and higher education. Mufwene (2002) indicated that economic survival and advantages to learning the dominant languages have led people to use the dominant language exclusively and to gradually stop learning their ancestral language. Malaysia's multiculturalism is a significant advantage, but to what extent ethnic minorities benefited from the multiculturalism remains questionable. Many ethnic minorities in Malaysia are facing huge challenges in maintaining and preserving their culture and identity (Gill et al., 2015; Lee, 2008). Many languages of the ethnic minorities are described as endangered languages in risk of extinction as a result of migration, attitudes, education, social and economic reasons (Ali, 2010).

In this digital era, ICT is seen as inseparable from the culture of ethnic minorities. The adoption of ICT and its impact on the culture of ethnic minorities has been debated over the past decades. Ethnic minorities' cultures have experienced significant challenges as a result of globalization (Ali, 2010). ICT has always been labelled as a catalyst that eroded the ethnic cultural identity. This flows from the argument that the ethnic identity and cultures are facing a crisis as rapid innovations and technologies, which are embedded with a variety of foreign values, tend to be imposing unsuitable foreign values onto the local minority groups (Dyson, 2004; Mustafa, 2006). Massive exposure to ICT has been identified as a probable element that used to support and accelerate the dominant influence of the Western-based modes of thought, information, values and cultures, which resulting in indigenous peoples having limited opportunities to strengthen their cultural legacy and language, as well as the decline of their cultural identity (Resta, 2011).

Despite the fact that ICT has long been associated with cultural erosion, some scholars argued that it has made tremendous contributions in cultural preservation and maintenance. Lieberman (2003) pointed out that although ICT causes inevitable clashes with local traditions, however, it can be used to preserve, promote, and strengthen the indigenous language and culture. This is critical because indigenous knowledge is in danger of extinction due to the difficulties in preserving it, and there is a pressing need to preserve indigenous knowledge using ICT (Ngcobo \& Obono, 2013). This is in accordance with Michael and Dunn (2006), who claimed that the prospective uses of ICT in important sectors are critical to the culture's survival. Harris and Harris (2011) stated that ICT has benefited the indigenous community in a remote area in Sarawak, Malaysia in terms of cultural transmission to the next generation. Similarly, Chikonzo (2006) highlighted the importance of ICT in preserving and disseminating indigenous knowledge to ensure its sustainability. Nonetheless, Goulding et al. (2020) suggested that the indigenous people should play the active role as the creator and 
controller of the digital culture rather than a passive consumer, to optimize the potential of technologies to strengthen and sustain the important aspects of material and immaterial indigenous culture.

Indeed, indigenous communities have benefited from the use of ICT to share communal and cultural information (Castleton, 2018). Nickerson and Kaufman (2005) argued that ICT can play a key role in cultural and linguistic preservation and promotion in new and exciting ways if used appropriately. For instance, a study carried out by Zabecki (2019) revealed that video games can promote and preserve indigenous cultures by altering the stereotypical image and negative attitudes towards the indigenous groups and help implement their languages in games. Therefore, ICT has emerged as an important platform for the community to find, learn and share their cultural information. The outbreak of the COVID-19 pandemic has threatened human lives in all ways, which has sent an alarming message that human needs a contingency method in enhancing their cultural preservation to ensure its sustainability. It does not mean to displace or overshadow the importance of in-person cultural transmission, but rather as an alternative to optimizing the dissemination of ethnic minorities' culture, thus strengthening their cultural sustainability.

ICT is seemingly an important alternative solution that provides a digital platform for the ethnic minorities in Malaysia to share their ideas, thoughts and knowledge related to their culture which is significantly useful in maintaining and promoting their culture (Khong, 2015). For instance, the Portuguese Settlement is the cultural heartland of the Malacca Portuguese community, but not all the Portuguese people were brought up in Malacca as the community has been scattered around for better education and employment opportunities. The Kristang ${ }^{1}$ language of the Portuguese community was not taught but rather passed down from generation to generation, implying that people residing in other states would not have the opportunity to learn it (Fernandis, 2003). Therefore, the learning process of the culture or the language can be facilitated and enhanced through ICT, if it is being used appropriately to educate and pass the cultural knowledge and language from one generation to the next. Some minorities youth, such as the Baba Nyonya community, have used social media to actively communicate their cultural events and traditions (refer Figure 1 and Figure 2), which helps to promote and preserve their cultural identity.

1 The Kristang (Portuguese Creole) language is a mixture of Malay and archaic Portuguese words with a sprinkling of Malay grammar 


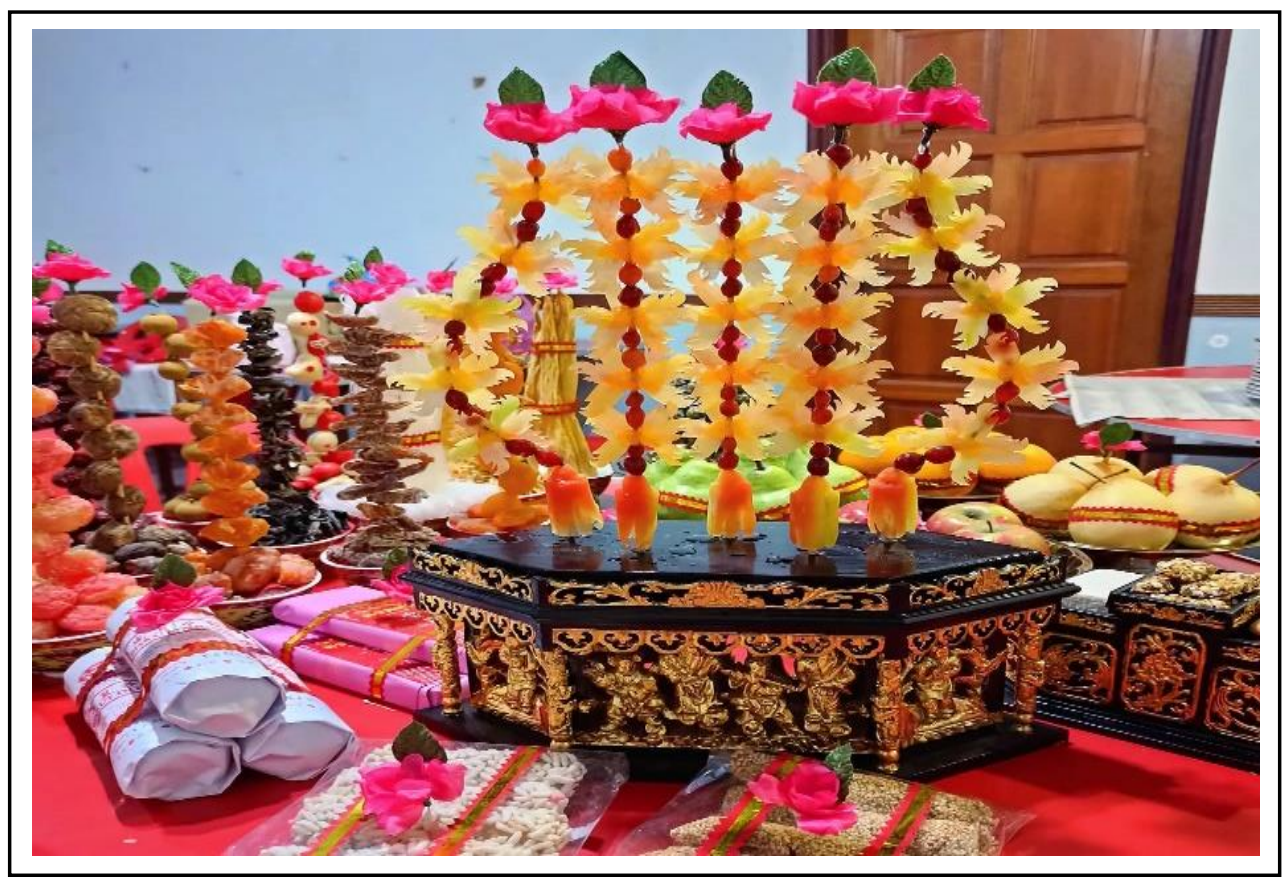

Figure 1. Preparation of Offerings Known as "Chanap"2 During Smayang Ti Gong ${ }^{3}$ Festival

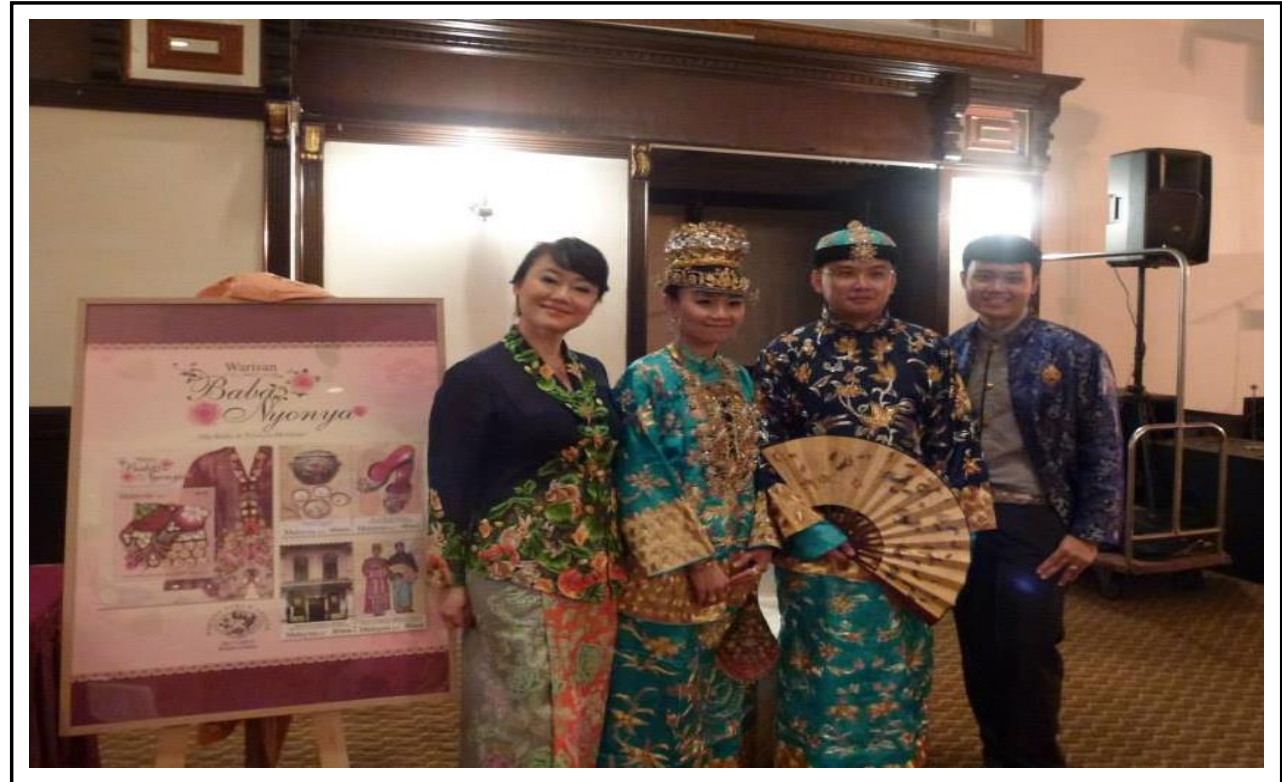

Figure 2. Baba Nyonya's Traditional Costume During Wedding Source: Baba Thien (2013)

${ }^{2}$ Chanap is one of the offerings put on the altar. The papaya is carved in the shape of crabs and flowers, and delicately strung together. Crab is pronounced "xie" in Chinese, which is close to the word "harmony." As a result, the Baba Nyonya community displays or offers Chanap to the deities or ancestors in the hopes of receiving a beautiful, peaceful, and harmonious existence in return. The preparation of Chanap is currently a vanishing craft, with just a handful of Baba Nyonya remaining in Malacca who know how to make it.

${ }^{3}$ Smayang Ti Gong or Bai Tian Gong (literally means "praying the Heaven God") is one of the important Chinese culture and traditions. Bai Tian Gong is performed and celebrated lively on the 9th day of the first month of the Lunar New Year, which is to celebrate the birth of the Jade Emperor or often known as Yu Huang Da Di. 
Although ICT is viewed as a strategic alternative for ethnic minorities to preserve their culture, this ideal thought will remain as a rhetoric if ethnic minorities' accessibility to ICT remains low due to poverty, inadequate infrastructure, a lack of ICT skills and knowledge, and stereotypical attitudes towards ICT. Indeed, the availability of resources plays a pivotal role in determining ICT adoption in cultural preservation (Gill et al., 2016). For instance, many indigenous communities are experiencing a digital divide because their residential area still does not have easy access to facilitate and encourage indigenous people to use ICT (Ishak \& Hassan, 2007). There are still many indigenous people who have yet to enjoy a proper foundation (Hunt, 1998). Undoubtedly, the indigenous people are facing difficulties to have access to digital information due to their disadvantaged socioeconomic position, level of literacy and skillbased capabilities (Samaras, 2005). Indeed, the process of marginalization widens the existing socioeconomic gap between the ethnic minorities and the mainstream society (Nicholas, 2000).

\section{Conclusion}

All segments of Malaysian society must benefit from the country's economic prosperity to create an advanced economy and inclusive nation. Generally, there is still a lack of opportunities for ethnic minority communities. Their problems are important and critical to be brought to the attention of the respective authorities. This is crucial as ICT plays a vital role in this knowledge-based digital era. It has significantly changed how societies interact and communicate with one another. The rapid innovations of ICT undoubtedly promote cultural exchange among the multiracial and multicultural society. ICT is described as a double-edged sword. Pessimistically, ICT could be the last straw that crushes the fast disappearing minorities' culture. On the other side, optimistically, ICT could be the light behind the tunnel which has emerged as a potential platform in enhancing the cultural preservation among ethnic minorities. It is hoped that more training and technical support will be provided to the ethnic minorities to enhance their ICT skills and knowledge to preserve their culture. The government should pay greater attention to the ethnic minorities through the introduction of fair policies and consistent development efforts to the ethnic minorities by intensifying their participation in ICT development. The socio-economic gaps among the minority ethnic groups need to be alleviated and prioritized.

Malaysia's national visions such as Vision 2020, the Shared Prosperity Vision 2030, National Transformation 2050 are unifying approaches, which emphasize celebrating cultural diversity and are against assimilation, thus inclusivity should be the top priority for all sorts of policies and development. Otherwise, the disparities existing between the ethnic minorities and the mainstream society will ensure that cultural preservation through ICT among ethnic minorities remains nothing more than rhetoric. Finally, consistent efforts must be made to reduce the digital divide among citizens without marginalising any minority groups, because ethnic minorities' distinct cultures are valuable assets that must be preserved. Only then can a comprehensive and inclusive development be realised.

\section{Acknowledgment}

This article is based on research funded by the Universiti Putra Malaysia's Research University Grant Scheme (RUGS). 


\section{References}

Aclar, A. (2011). Exploring the aspects of the digital divide in a developing country. Issues in Informing Science and Information Technology, 8, 231-244.

Ali, H. M. B. M. (2010). The maintenance of Malaysia's minority languages. [Paper presentation]. International Conference on Minority and Majority: Language, Culture and Identity, Sarawak, Malaysia http://irep.iium.edu.my/9829/4/ICMM2010_p27.pdf

Apulu, I., \& Latham, A. (2011). Drivers for information and communication technology adoption: A case study of Nigerian small and medium-sized enterprises. International Journal of Business and Management, 6(5), 51-60.

Arabestani, M., \& Edo, J. (2011). The Semai's response to missionary work: From resistance to compliance. Anthropological Notebooks, 17(3), 5-27.

Arrawatia, M. A., \& Meel, P. (2012). Information and communication technologies \& woman empowerment in India. International Journal of Advanced Research in Computer Engineering \& Technology (IJARCET), 1(8), 99-104.

Ashraf, M. M., Grunfeld, H., \& Quazi, A. (2015). Impact of ICT usage on indigenous peoples' quality of life: Evidence from an Asian developing country. Australasian Journal of Information Systems, 19, 1-16.

Bhawna. (2019). A study on digitalization of education through understanding ICT. Globus Journal of Progressive Education, 8(2), 4-6.

Borgmann, A. (2006). Technology as a cultural force: For Alena and Griffin. The Canadian Journal of Sociology, 31(3), 351-360.

Carey, I. (1976). Orang Asli: The aboriginal tribes of Peninsular Malaysia. Oxford University Press.

Castleton, A. (2018). Technology and Inuit identity: Facebook use by Inuit youth. Alternative, 14(3), 228-236.

Chikonzo, A. (2006). The potential of information and communication technologies in collecting, preserving and disseminating indigenous knowledge in Africa. The International Information \& Library Review, 38(3), 132-138.

Department of Statistics Malaysia. (2018). Malaysia Digital Economy 2018. https://dosm.gov.my/v1/index.php?r=column/ctheme\&menu_id=b0pIV1E3RW40VW RTUkZocEhyZ1pLUT09\&bul_id=UERrcjExbnRKd3NwQ0Y3V011RngyQT09\#

Department of Statistics Malaysia. (2019). ICT Use and Access by Individuals and Households Survey Report 2019.

https://www.dosm.gov.my/v1/index.php?r=column/pdfPrev\&id=SFRacTRUMEVRUFo1 Ulc4Y1JILzBqUT09

Dyson, L. E. (2004). Cultural issues in the adoption of information and communication technologies by Indigenous Australians. In F. Sudweeks \& C. Ess (Eds.), Proceedings of the Cultural Attitudes towards Communication and Technology (pp. 58-71). Perth: Murdoch University.

Economic Planning Unit Malaysia. (2001). Eighth Malaysia Plan, 2001-2005. http://www.epu.gov.my/en/eighth-malaysia-plan-2001-2005

Economic Planning Unit Malaysia. (2006). Ninth Malaysia Plan, 2006-2010. http://www.epu.gov.my/en/ninth-malaysia-plan-2006-2010

Edo, J., Awang, S. N., Fadzil, K. S., Zainol, R., \& Ibrahim, W. S. W. (2013). Pendidikan dan hak asasi kanak-kanak: Satu tinjauan cabaran dan hala tuju pendidikan awal kanak-kanak Orang Asli di Kompleks Belum-Temenggor. Man and Society, 23, 1-18. 
Ekeanyanwu, N. T. (2010). Theorizing cultural development vis-à-vis cultural imperialism theory. Critique and Application of Communication Theories, 28-49.

Fernandis, G. (2003). The Portuguese community at the periphery: A minority report on the Portuguese quest for Bumiputera status. Kajian Malaysia, 21(1), 285-301.

Gill, S. S., Amir Zal W. A., \& Ma'rof, R. (2009). Jurang digital belia Orang Asli di Bukit Lanjan. Malaysian Journal of Youth Study, 1(1), 69-97.

Gill, S. S., Talib, A. T., \& Kunasekaran, P. (2015). Social issues and identity threat of the Sikh minority community in Malaysia. Asian Culture and History, 7(2), 47-51.

Gill, S. S., Talib, A. T., Khong, C. Y., \& Kunasekaran, P. (2016). Exploring the role of resources in ethnic minorities' adoption of information and communication technology in preserving their cultural identity in Malaysia. Asian Culture and History, 8(1), 69-75.

Goulding, A., Campbell-Meier, J., \& Sylvester, A. (2020). Indigenous cultural sustainability in a digital world: Two case studies from Aotearoa New Zealand. Lecture Notes in Computer Science, 66-75.

Harris, C. A., \& Harris, R. W. (2011). Information and communication technologies for cultural transmission among indigenous peoples. The Electronic Journal of Information Systems in Developing Countries, 45(1), 1-19.

Hashim, R., Idris, K. S., Ustadi, Y. A., Merican, F. M., \& Fuzi, S. F. S. M. (2012). Digital inclusion and lifestyle transformation among the Orang Asli: Sacrificing culture for modernity. Asian Social Science, 8(12), 80-87.

Hunt, A. W. (1998). Orang Asli dan cabaran pembangunan. In H. M. Nor (Eds.). Warga pribumi menghadapi cabaran pembangunan (pp. 76-87). Penerbit Universiti Kebangsaan Malaysia.

Ishak, M. S., \& Hassan, M. A. (2007). Keengganan memiliki computer dan Internet di rumah: Satu persoalan jurang digital dalam kalangan masyarakat Malaysia. [Paper presentation]. International Conference on Media and Communication, Malaysia.

Kaware, S. S., \& Sain, S. (2015). ICT application in education: an overview Sudhir. International Journal of Multidisciplinary Approach and Studies, 2(1), 25-32.

Khong, C. Y. (2015). Adoption of ICT and its impact on cultural identity sustainability of ethnic minorities in Peninsular Malaysia. [Unpublished Master dissertation]. Universiti Putra Malaysia.

Kijai, J. (2012). Factors related to language shift among the Tindal population in Ratau, Kota Belud, Sabah. Human Behavior, Development and Society, 7(1), 4-13.

Lee, S. K. (2008). The Peranakan Baba Nyonya culture: Resurgence or disappearance? SARI: Jurnal Alam dan Tamadun Melayu, 26, 161-170.

Lieberman, A. E. (2003). Taking ownership: Strengthening indigenous cultures and languages through the use of ICTs.

http://www.guidestarinternational.org/documents/Takingownership-Strengthening Indigenous Cultures and Languages through the Use ICTs.pdf

Liu, J. (2021). Proselytising the indigenous majority: Chinese Christians and interethnic relations in East Malaysia, Anthropological Forum, 31(3), 1-19.

Malaysian Communications and Multimedia Commission (2014). Internet Users Survey. https://www.mcmc.gov.my/skmmgovmy/media/General/pdf/Internet-Users-Survey2014.pdf

Masron, T., Masami, F., \& Ismail, N. (2013). Orang Asli in Peninsular Malaysia: population, spatial distribution and socio-economic condition. J Ritsumeikan Soc Sci Humanit, 6, 75115. 
Menon, J., \& Fink, A. (2019). The Fourth Industrial Revolution and Its Implications for Regional Economic Integration in ASEAN. Journal of Asian Economic Integration, 1(1), 32-47.

Michael, K., \& Dunn, L. (2006). The use of information and communication technology for the preservation of aboriginal culture: The Badimaya people of Western Australia. In L. Dyson (Eds.), Information Technology and Indigenous People. (pp. 170-174). Idea Group Publishing.

Ministry of Education Malaysia (2013). Malaysia Education Blueprint 2013-2025. https://www.moe.gov.my/menumedia/media-cetak/penerbitan/dasar/1207malaysia-education-blueprint-2013-2025/file

Moorthy, R. (2009). The evolution of the Chitty community of Melaka. Jebat: Malaysian Journal of History, Politics \& Strategic Studies, 36, 1-15.

Mufwene, S. S. (2002). Colonisation, globalisation, and the future of languages in the twentyfirst century. International Journal of Multicultural Societies. 4(2), 1-48.

Mustafa, K. O. C. (2006). Cultural identity crisis in the age of globalization and technology. The Turkish Online Journal of Educational Technology, 5(1), 37-43.

Ngcobo, K. M., \& Obono, S. E. (2013). Modelling ICT adoption factors for the preservation of indigenous knowledge. International Journal of Social, Behavioral, Educational, Economic, Business and Industrial Engineering, 7(1), 223.

Nickerson, M., \& Kaufman, J. (2005). Aboriginal culture in the digital age. Policy, Politics \& Governance, 10, 1-8.

Nicholas, C. (1996). The Orang Asli of Peninsular Malaysia. In C. Nicholas, \& R. Singh (Eds.), Indigenous peoples of Asia: Many peoples, one struggle. Asia Indigenous Pact.

Nicholas, C. (2000). The Orang Asli and the contest for resources: Indigenous politics, development and identity in Peninsular Malaysia. International Work Group for Indigenous Affairs.

Nobuta, T. (2007). Islamization Policy toward the Orang Asli in Malaysia. Bulletin of the National Museum of Ethnology, 31(4), 479-495.

Oh, Y., Razak, N. F. A. H. A., Wee, D. H. T., Ching, E. L., \& Rahman, Z. (2019). The development of Nyonya cuisine in the Malay Archipelago: Penang and Malacca Nyonya cuisine. Journal of Ethnic Foods, 6(1), 1-10.

Osman, M. N. (2007). The digital divide issues: is the gap getting bigger? Malaysian Journal of Communication, 23, 1-13.

Pillai, S., Soh, W. Y., \& Yusuf, Y. Q. (2015). Perceptions about one's heritage language: The case of the Acehnese in Kampung Aceh and Malacca Portuguese-Eurasians in the Portuguese settlement in Malaysia. Kemanusiaan: The Asian Journal of Humanities, 22(2), 67-92.

Pinto, R. (2019). The effect of Western formal education on the Ghanaian educational system and cultural identity. The Journal of Negro Education, 88(1), 5-16.

Reid, A. (1997). Endangered identity: Kadazan or Dusun in Sabah (East Malaysia). Journal of Southeast Asian Studies, 28(1), 120-136.

Resta, P. (2011). ICTs and Indigenous People. UNESCO Institute for Information Technologies in Education.

Rosnon, M. R., \& Talib, M. A. (2019). Indigenous education rights: The Malaysian case. International Journal of Academic Research in Business and Social Sciences, 9(10), 149167. 
Roztocki, N., Soja, P., \& Weistroffer, H. R. (2019). The role of information and communication technologies in socio-economic development: towards a multi-dimensional framework. Information Technology for Development, 25(2), 171-183.

Samaras, K. (2005). Indigenous Australians and the 'digital divide'. Libri, 55(2-3), 84-95.

Sawyer, R., \& Chen, G. M. (2012). The impact of social media on intercultural adaptation. Intercultural Communication Studies, 21, 151-169.

Sintang, S., Hambali, K., Baharuddin, A., Ahmad, M., Nor, M. R. M., \& Kadir, N. A. A. (2014). Conversion to Islam and interfaith marriage in" Sabah", Malaysia. The Ahfad Journal, 31(1), 46.

Snyder, H. (2019). Literature review as a research methodology: An overview and guidelines. Journal of Business Research, 104, 333-339.

United Nations (2003). Tools for development: Using ICT to achieve the millennium development goals.

http://www.itu.int/net/wsis/stocktaking/docs/activities/1103056110/ICTMDGFinal.pd $f$

UNESCO (2011). Atlas of the world's languages in danger. http://unesdoc.unesco.org/images/0019/001924/192416e.pdf

Wurm, S. A. (1991). Language death and disappearance: Causes and circumstances. Diogenes, 39(153), 1-18.

Yamamichi, M. (2011). The role of mobile-enabled social media in social development. World Bank.

Zabecki, K. (2019). Promoting and preserving indigenous languages and cultures in the Americas through video games. Handbook of the Changing World Language Map, 1-18.

Zuppo, C. M. (2012). Defining ICT in a boundaryless world: The development of a working hierarchy. International journal of managing information technology, 4(3), 13-22. 